\title{
PERTANGGUNGJAWABAN PIDANA PEMEGANG SAHAM DAN DIREKSI TERHADAP KORPORASI YANG DIPIDANAKAN
}

\author{
Heffinur \\ Mahasiswa Program Doktor Ilmu Hukum, Universitas Jayabaya, Jakarta \\ dan Inspektur Investigasi, Inspektorat Jenderal Kementerian Agama RI \\ Korepondensi: heffinur.h@yahoo.com
}

\begin{abstract}
Abstrak
Kejahatan korporasi merupakan salah satu tindak pidana yang timbul seiring dengan perkembangan perekonomian dan teknologi. Persoalan yang mengemuka yaitu bagaimana tanggung jawab perusahaan sebagai badan hukum, sementara dalam kaidah Hukum Pidana belum sepenuhnya menjangkau tindak pidana tersebut. Tulisan ini bermaksud menguraikan pertanggungjawaban pidana korporasi, utamanya pemegang saham dan direksi manakala ada tindak pidana yang dilakukan.
\end{abstract}

Kata-kata Kunci: Kejahatan; Korporasi; Direksi; Pemegang Saham.

\begin{abstract}
Corporate crime is a category of crimes that emerge along with the economic and technological development. The issue raised in this article is how is the criminal responsibility for the company as a legal entity. This is crucial since the rules of the Criminal Law has not fully reach the criminal act performed by corporations. This paper intends to outline the criminal liability of corporations, particularly their main shareholders and directors when there is a criminal offense committed.
\end{abstract}

Key words: Crime; Corporation; Directors; Shareholders. 


\section{PENDAHULUAN}

Konsep kejahatan korporasi (corporate crime) berkembang dengan semakin majunya kegiatan perekonomian dan teknologi. Corporate crime bukanlah barang baru, melainkan barang lama yang senantiasa berganti kemasan. Tidak ada yang dapat menyangkal bahwa perkembangan zaman serta kemajuan peradaban dan teknologi turut disertai dengan perkembangan tindak kejahatan beserta kompleksitasnya. Di sisi lain, ketentuan hukum pidana yang berlaku di Indonesia belum dapat menjangkaunya dan senantiasa ketinggalan untuk merumuskannya. Salah satu contohnya adalah Tindak Pidana Pencucian Uang (money laundering) yang baru dikriminalisasi secara resmi pada tahun 2002. Contoh lain adalah kejahatan dunia maya (cyber crime) yang sampai saat ini pengaturannya masih mengundang tanda tanya. Akibatnya, banyak bermunculan tindakan-tindakan atau kasus-kasus illegal, namun tidak dapat dikategorikan sebagai crime. ${ }^{1}$

Tindak pidana (crime) dapat diidentifikasi dengan timbulnya kerugian (harm), yang kemudian mengakibatkan lahirnya pertanggungjawaban pidana atau criminal liability. ${ }^{2}$ Hal yang mengundang perdebatan adalah bagaimana pertanggungjawaban korporasi atau corporate criminal liability mengingat dalam Kitab Undang-undang Hukum Pidana (KUHP) Indonesia yang dianggap sebagai subyek hukum pidana hanyalah manusia (naturlijkee person). Di samping itu, KUHP juga masih menganut asas sociates delinquere non potest di mana badan hukum atau korporasi dianggap tidak dapat melakukan tindak pidana. ${ }^{3}$

Pembahasan Rancangan Kitab Undang-Undang Hukum Pidana (RKUHP) memasukkan prinsip-prinsip pertanggungjawaban pidana korporasi. Ada tujuh pasal dalam RKUHP yang mengatur pertanggungjawaban pidana korporasi, yaitu Pasal 47, 48, 49, 50, 51, 52, dan 53. Pasal 47 menyatakan "korporasi merupakan subyek tindak pidana." Pasal 50 menyatakan, "korporasi dapat dipertanggungjawabkan secara pidana terhadap suatu perbuatan yang dilakukan untuk dan atau atas nama korporasi, jika perbuatan tersebut termasuk dalam lingkup usahanya sebagaimana ditentukan dalam anggaran dasar atau ketentuan lain yang berlaku bagi korporasi yang bersangkutan." Tim perumus dari Dewan Perwakilan Rakyat (DPR) menilai perkembangan bentuk, motif, modus operandi maupun pelaku tindak pidana di Indonesia sangat dinamis. Makin banyak tindak pidana ekonomi yang melibatkan korporasi dan sumber daya di dalamnya. ${ }^{4}$

Singgih, Kejahatan Korporasi yang Mengerikan (Pusat Studi Hukum Bisnis Fakultas Hukum Universitas Pelita Harapan 2005) 9.

2 Hyman Gross, A Theory of Criminal Justice (Oxford University Press 1979) 114.

3 Rusmana, 'Pertanggungjawaban Korporasi dalam Tindak Pidana Perikanan' <http:// www.solusihukum.com/artikel/artikel45.php> diakses 3 Februari 2014.

4 Erwin Purba, 'Menghukum Korporasi: Mengurangi Kerugian Negara' Majalah Forum Keadilan (2013) Mei, 43-44. 
Dalam berbagai sistem hukum yang ada di dunia, termasuk Indonesia, korporasi adalah subjek hukum buatan yang dapat dikenakan pertanggungjawaban pidana. Sebagai subjek hukum (rechtpersoon), korporasi bukan hanya diberi kewenangan untuk bertindak seperti individu, tetapi ditambah dengan kebebasan yang besar dalam menjalankan kegiatan ekonomi. Pada era akhir dasawarsa 1980-an, korporasi di bidang perbankan berkembang pesat karena dukungan kebijakan dari pemerintah saat itu. Namun demikian, hal tersebut ternyata diikuti pula dengan terjadinya krisis perbankan pada tahun 1997-1998, yang pada akhirnya menimbulkan berbagai masalah likuiditas.

Untuk mengatasi krisis perbankan tersebut, negara c.q Bank Indonesia mengucurkan Bantuan Likuiditas Bank Indonesia (BLBI), yang diharapkan membantu korporasi perbankan untuk keluar dari krisis. Nyatanya, dana BLBI yang berjumlah ratusan trilliun rupiah tersebut banyak dimanipulasi untuk kepentingan sekelompok orang yang memegang peranan dalam beroperasinya korporasi debitur BLBI. Masyarakat belum puas dengan sanksi yang selama ini telah diberikan dalam penyelesaian kasus BLBI.

Di beberapa negara seperti Perancis, Finlandia, Norwegia dan Australia, telah diatur mengenai pertanggungjawaban pidana korporasi dalam masing-masing undang-undang pidananya. Dengan demikian, apabila kasus seperti BLBI terjadi di negara-negara tersebut, maka selain pengurus atau pejabat korporasi dapat dipidana, terhadap korporasi itu sendiri akan dikenakan pertanggungjawaban pidana korporasi. Dengan menggunakan teori vicarious liability, strict liability maupun identification, maka perbuatan pidana yang telah dilakukan dapat dielaborasi dengan berorientasi pada perbuatan hukum yang dilakukan oleh korporasi. Dengan demikian, penyelesaian kasus BLBI dapat dikonstruksikan dengan lebih akurat, khususnya penyelesaian terhadap perbuatan pidana yang telah mengakibatkan kerugian keuangan negara tersebut.

\section{PEMBAHASAN}

\section{Meninjau Kembali Potensi Pertanggungjawaban Hukum oleh Korporasi}

KUHP belum mengenal adanya ketentuan pidana yang menetapkan korporasi sebagai subjek yang dapat dikenakan pidana. Hal ini terlihat dalam ketentuan umum KUHP yang menyebutkan berlakunya peraturan perundang-undangan Indonesia bagi setiap orang. Terminologi lain yang dipakai dalam KUHP adalah "warga negara" sebagaimana disebutkan dalam Pasal 5 KUHP, yang pada intinya menetapkan berlakunya peraturan perundang-undangan Indonesia bagi warga negara Indonesia yang melakukan kejahatan tertentu, di luar wilayah Indonesia. Namun demikian, dalam perkembangannya, korporasi kemudian menjadi subjek hukum dalam rumusan ketentuan pidana.

Ketetapan untuk meminta pertanggungjawaban korporasi dalam 
bentuk pertanggungjawaban pengurusnya dapat dilihat pada ketentuan Pasal 46 ayat (2) UndangUndang Nomor 7 Tahun 1992 tentang Perbankan sebagaimana diubah dengan Undang-Undang Nomor 10 Tahun 1998 (UU Perbankan): "Dalam hal kegiatan sebagaimana dimaksud dalam ayat (1) dilakukan oleh badan hukum yang berbentuk perseroan terbatas, perserikatan, yayasan atau koperasi, maka penuntutan terhadap badanbadan dimaksud dilakukan baik terhadap mereka yang memberi perintah melakukan perbuatan itu atau yang bertindak sebagai pimpinan dalam perbuatan itu atau terhadap keduanya." Dari rumusan pasal tersebut, jelas bahwa para pengurus yang berwenang untuk memberikan perintah kepada bawahannya dalam korporasi perbankan tersebut yang nantinya dapat dipertanggungjawabkan secara pidana.

Selain dapat dipertanggungjawabkan secara pidana melalui pengurusnya, korporasi juga dapat menjadi subjek hukum yang dapat dipertanggungjawabkan secara pidana. Dalam peraturan perundang-undangan khusus, diatur mengenai ketentuan ini. Dalam Undang-Undang Nomor 15 Tahun 2002 tentang Tindak Pidana Pencucian Uang sebagaimana diubah dengan Undang-Undang Nomor 25 Tahun 2003 (UU TPPU), secara tegas disebutkan dalam ketentuan umum bahwa pengertian "setiap orang” adalah orang perseorangan atau korporasi. Selain itu, dipertegas pula definisi mengenai "korporasi" yaitu "kumpulan orang dan/atau kekayaan yang terorganisasi baik merupakan badan hukum maupun bukan badan hukum."

Dengan demikian, semakin jelas bahwa konsepsi korporasi sebagai subjek hukum pidana ada dalam hukum positif. Ancaman sanksi pidana yang dapat dikenakan kepada korporasi adalah sebagaimana disebutkan dalam Pasal 5 UU TPPU, yaitu:

(1) Pidana pokok yang dijatuhkan terhadap korporasi adalah pidana denda, dengan ketentuan maksimum pidana denda ditambah $1 / 3$ (satu per tiga).

(2) Selain pidana denda sebagaimana dimaksud dalam ayat (1) terhadap korporasi juga dapat dijatuhkan pidana tambahan berupa pencabutan izin usaha dan/atau pembubaran korporasi yang diikuti dengan likuidasi.

Dalam hukum dikenal pengertian subjek hukum yang dalam istilah Belanda meliputi natuurlijke persoon dan rechtpersoon. Natuurlijke persoon adalah manusia yang memiliki kewenangan untuk bertindak dalam lapangan hukum, khususnya hukum perdata. Rechtpersoon ialah badan hukum yang diberi kewenangan oleh undang-undang untuk dapat bertindak sebagaimana manusia. Di Indonesia, badan hukum dapat berupa: Perum, Persero, Perseroan Terbatas, Yayasan dan Koperasi, serta Maskapai Andil Indonesia yang telah dihapus sejak tanggal 7 Maret 1998. Di antara organisasi-organisasi tersebut, Perseroan Terbatas (PT) adalah yang paling populer dan yang paling banyak digunakan sebagai alat oleh para pengusaha untuk melakukan kegiatan di bidang ekonomi. 
Pengertian korporasi diambil dari istilah dalam bahasa Inggris corporation yang berarti sekelompok orang yang oleh undang-undang diperbolehkan untuk melakukan perbuatan sebagaimana seorang individu sebagai subjek hukum, yang berbeda dengan para pemegang sahamnya. ${ }^{5}$ Oleh karena sasarannya adalah mencari keuntungan bagi pemegang saham dan perusahaan itu sendiri, maka korporasi, baik itu dalam bentuk PT. Persero maupun Perseroan Terbuka, selalu bersifat ekspansif dan penuh dinamika dalam mengikuti perkembangan ekonomi yang demikian cepat. Salah satu ciri dari korporasi yang demikian adalah selalu memerlukan investasi untuk menunjang ekspansi bisnis yang ditargetkan.

Menurut David J. Rachman dalam bukunya Business Today, secara umum korporasi memiliki lima ciri penting, yaitu: (a) merupakan subjek hukum buatan yang memiliki kedudukan hukum khusus; (b) memiliki jangka waktu hidup yang tak terbatas; (c) memperoleh kekuasaan (dari negara) untuk melakukan kegiatan bisnis tertentu; (d) dimiliki oleh pemegang saham; (e) tanggung jawab pemegang saham terhadap kerugian korporasi biasanya sebatas saham yang dimilikinya. ${ }^{6}$ Legitimasi kedudukan dan peranan yang diperoleh dari negara merupakan sarana yang sangat membantu sebuah korporasi dalam melaksanakan kegiatannya. Dukungan peraturan perundang-undangan yang diadakan secara khusus untuk mengatur suatu korporasi, telah memberikan kedudukan yang mantap bagi keberadaan korporasi di Indonesia. Jika dibandingkan dengan para pengusaha yang tergabung dalam badan-badan usaha non-korporasi, korporasi jauh lebih kuat, ditinjau dari aspek ekonomi, aspek politik maupun aspek hukum.

Semua hal di atas diperoleh dari lembaga dan pranata hukum yang mengatur mengenai kegiatan ekonomi dan perdagangan. Kebebasan ruang gerak yang diberikan kepada korporasi dimaksudkan untuk memberikan kesejahteraan kepada masyarakat luas, sehingga tujuan memajukan kesejahteraan umum yang diamanatkan oleh Pembukaan Undang-Undang Dasar Negara Republik Indonesia Tahun 1945 dapat terwujud. Pasal 33 ayat (1) UUD NRI 1945 menyebutkan bahwa perekonomian disusun sebagai usaha bersama berdasar atas asas kekeluargaan, sehingga koperasi sebenarnya diharapkan menjadi sokoguru perekenomian nasional yang dapat meningkatkan taraf hidup bangsa Indonesia. Namun pada kenyataannya korporasi dan konglomerasi yang akhirnya menguasai dan mendominasi kegiatan di sektor ekonomi, dengan bertindak sebagai pelaku utama.

Hakikat korporasi dapat dilihat dari pernyataan klasik Viscount Haldane L.C.: "Korporasi adalah suatu abstraksi. Ia tidak lagi memiliki pikirannya sendiri dibanding dengan tubuhnya sendiri;

Bryan A. Garner ed., Black's Law Dictionary (West Publishing Co. 2003) 147.

I.S. Susanto, Kejahatan Korporasi, (Badan Penerbit Universitas Diponegoro 1995) 15. 
kehendak yang dijalankan dan bersifat mengarahkan harus secara konsisten dilihat pada seseorang yang untuk tujuan tertentu mungkin disebut agen/ wakil, tetapi yang sebenarnya mengarahkan pikiran dan kehendak dari korporasi, (yaitu) ego dan pusat korporasi." ${ }^{7}$ Pernyataan ini sejalan dengan pendapat yang mengatakan bahwa korporasi dapat melakukan kejahatan itu sendiri, yaitu dengan melalui pejabat seniornya yang memiliki kedudukan dan kekuasaan untuk berperan sebagai otak dari korporasi. Dalam upaya menggambarkan korporasi sebagai subjek hukum yang perbuatannya dilihat dari perbuatan para pegawai yang mewakilinya, Lord Justice Denning menjelaskannya secara metaforis:

A company may in many ways be likened to a human body. It has a brain and a nerve centre which control what it does. It also has hands which holds the tools and act in accordance with directions from the centre. Some of the people of the company are mere servants and agent who are nothing more than hands to do the work and cannot be said to represent the mind or will. Others are directors and managers who represent the directing mind and will of the company, and control what it does. The state of mind of these managers are the state of mind of the company and is treated by the law as such. So you will find that in cases where the law requires a personal fault as a condition of lability in tort, the fault of the manager will be the personal fault of the company ... So also in the criminal law. In cases where the law requires a guilty mind as a condition of a criminal offence, the guilty mind of the directors or managers will render the company itself guilty. ${ }^{8}$

Dengan demikian, pejabat senior yang dimaksud oleh hukum adalah orang-orang yang mengendalikan korporasi, baik sendirian maupun bersama-sama dengan pejabat senior yang lain. Para pejabat senior tersebut mencerminkan dan mewakili pikiran atau kehendak dari korporasi. Hal inilah yang membedakan mereka dengan para pegawai biasa dan agen yang hanya melaksanakan apa yang telah diarahkan oleh pejabat senior. Para pengendali korporasi dalam pengertian luas adalah "para direktur dan manajer" serta pemegang saham.

Kejahatan korporasi adalah fenomena yang tidak banyak mendapatkan perhatian dari penegak hukum, sehingga masyarakat juga ikut lalai memberikan perhatian. Kelalaian bersama ini dikenal dengan istilah collective ignorance. Sebab dari timbulnya hal ini sebenarnya tidak terlalu sulit untuk diungkap dan dikaji secara lebih mendalam. Kejahatan korporasi seringkali tidak tampak karena kompleksitas dan perencanaan yang matang, serta pelaksanaannya yang halus, karena penuntutan dan penegakan hukum yang lemah, karena ketiadaan hukum positif yang mengaturnya, atau juga karena sanksi sosial dan hukum yang lunak. ${ }^{9}$ Kejahatan korporasi maupun kejahatan bisnis memiliki dimensi ekonomi, sebagaimana dikemukakan oleh

Peter Gillies, Criminal Law (The Law Book Co. 1990) 126.

Ibid. 136.

Steven Box, Power, Crime and Mystification (Tavistock Publication 1983) 16. 
Conklin: "Business crime is an illegal act, punishable by a criminal sanction, which is committed by an individual or a corporation in the course of a legitimate aoccupation or pursuit in the industrial or commercial sector for the purpose of obtaining money or property, avoiding the payment of money or the loss of property, or obtaining business or personal advantage." 10

Definisi seperti ini memang dapat dipahami, dengan catatan bahwa dalam mencapai tujuan ekonomisnya, korporasi menyebabkan dampak fisik, selain dampak ekonomi yang telah digambarkan di atas. Schrager dan Short mendefinisikannya sebagai berikut: "Organizational crimes are illegal acts of omission or comission of an individual or a group of individuals in a legitimate formal organization in accordance whith the operative goals of organization which have a serious physical or economic impact on employees, consumers or the general public."11 Roeslan Saleh menyatakan bahwa khususnya untuk pertanggungjawaban pidana dari badan hukum, asas kesalahan tidak mutlak berlaku. ${ }^{12}$ Di beberapa negara, untuk tindak pidana tertentu, seperti tindak pidana lingkungan, dikenal doktrin yang mengecualikan syarat umum adanya unsur kesalahan dalam tindak pidana. Doktrin tersebut dikenal dengan nama: strict liability dan vicarious liability.
Menurut Curzon, adanya doktrin strict liability didasarkan pada alasanalasan sebagai berikut. Pertama, adalah sangat esensiil untuk menjamin dipatuhinya peraturan-peraturan penting tertentu yang diperlukan untuk kesejahteraan masyarakat. Kedua, pembuktian akan adanya mens rea akan menjadi sangat sulit untuk pelanggaranpelanggaran yang berhubungan dengan kesejahteraan masyarakat itu. Ketiga, tingginya tingkat "bahaya sosial” yang ditimbulkan oleh perbuatan yang bersangkutan. ${ }^{13}$

Di Inggris, sejak tahun 1944 telah mantap pendapat bahwa suatu korporasi dapat bertanggung jawab secara pidana, baik sebagai pembuat atau peserta untuk tiap delik, meskipun disyaratkan adanya mens rea dengan menggunakan teori identifikasi (identification test theory) atau directing mind theory. Dengan demikian, berbeda dengan di Indonesia, pertanggungjawaban korporasi tidak terbatas hanya pada delik-delik tertentu, meskipun tidak semua delik dapat dilakukan oleh korporasi.

Dengan asas identifikasi, korporasi dipandang sebagai orang pribadi atau persoon, yang dapat melakukan delik dalam common law yaitu bermufakat untuk menipu, suatu delik yang mensyaratkan adanya mens rea dan tidak dimungkinkan adanya vicarious liability. Asas identifikasi beranggapan bahwa perbuatan dan sikap batin dari

Ibid. 20

Ibid.

Muladi dan Barda Nawawi Arief, Teori-teori dan Kebijakan Pidana (Alumni, 1998) 140.

Ibid. 141 . 
pejabat korporasi tertentu, merupakan perbuatan dan sikap batin dari korporasi. Dari aspek pertanggungjawaban pidana, korporasi dipandang harus bertanggungjawab tidak saja karena perbuatan para pejabatnya, melainkan karena korporasi itu sendiri telah melakukan delik secara pribadi.

Kejahatan korporasi merupakan problem yang sangat sulit apabila ditinjau dari segi pertanggungjawaban pidana. Dalam perkembangan selanjutnya, justru korporasi ini yang banyak terlibat dalam kejahatan bisnis yang merugikan dan sangat berpengaruh terhadap kehidupan ekonomi dan pembangunan. Pengaruh tersebut dapat berupa pengaruh terhadap aspek lingkungan, sumber energi, politik, kebijaksanaan luar negeri dan sebagainya. Ralph Nader mengatakan bahwa "Corporate crime demonstrates the destructive impact such behaviour has on our politics, environment, consumers, workers, shareholders, small taxpayers, foreign policy and future generations." 14

Pengertian bahwa korporasi adalah kesatuan dalam pencapaian tujuan, membuatnya kriminogen secara inhern. Sebab utamanya adalah karena upaya mencapai tujuan tersebut dilaksanakan dalam lingkungan yang tidak pasti dan tidak dapat diperkirakan dengan akurat, sementara kesempatan yang diberikan oleh hukum seringkali terbatas dan mengikat. Konsekuensi dari itu, para eksekutif melihat pada alternatif lain, termasuk penghindaran dan pelanggaran hukum, serta berusaha mencapai alternatif tersebut karena dinilai lebih unggul dibanding alternatif lain yang jelas sah menurut hukum dan sebenarnya dapat digunakan.

Ketidakpastian lingkungan korporasi dapat disebabkan oleh berbagai macam sumber. Namun, terdapat 5 (lima) sumber utama yang dapat mengganggu kemampuan korporasi untuk memenuhi tujuannya dengan mudah tanpa menyimpang dari ketentuan hukum. Sumber-sumber jika dirinci adalah sebagai berikut. Pertama, kompetitor, yaitu melalui terobosan dalam bidang teknologi, struktur harga, teknik pemasaran, merger, perluasan atau penambahan pasar. Kedua, pemerintah, yaitu perluasan peraturan yang mencakup lebih banyak kegiatan korporasi baik melalui hukum yang baru maupun penegakan hukum yang lebih keras. Ketiga, pegawai, yaitu dengan kegiatan yang kolusif sifatnya, tetapi khususnya mereka yang tergabung dalam serikat buruh yang militan terhadap masalah upah dan membuat tuntutan yang radikal mengenai perbaikan kondisi kerja/pegawai. Keempat, konsumen, khususnya ketika permintaan produk demikian elastis dan akibatnya (konsumen) menjadi bertingkah, atau ketika "konsumerisme" lebih berkuasa dan membuat setiap pertanyaan terhadap kerja korporasi tampak jelas. Kelima, masyarakat, khususnya melalui pertumbuhan

14 Soedjono Dirdjosisworo, Kejahatan Bisnis - Orientasi dan Konsepsi (Mandar Maju 1994) 1. 
kesadaran terhadap lingkungan hidup bagi pemeliharaan udara, tanah dan sumber daya alam. ${ }^{15}$

\section{Teori-Teori tentang Pertanggung jawaban Pidana Korporasi}

\section{Strict Liability}

Menurut teori ini, korporasi dianggap bertanggung jawab atas perbuatan yang secara fisik dilakukan oleh pemegang saham, pengurus, agen, wakil atau pegawainya. Di bidang hukum pidana, strict liability berarti niat jahat atau mens rea tidak harus dibuktikan dalam kaitan dengan satu atau lebih unsur yang mencerminkan sifat melawan hukum atau actus reus, meskipun niat, kecerobohan atau pengetahuan mungkin disyaratkan dalam kaitan dengan unsur-unsur tindak pidana yang lain.

Menurut Barda Nawawi Arief, teori tersebut dapat disebut juga dengan doktrin pertanggungjawaban pidana yang ketat menurut undang-undang. ${ }^{16}$ Kerangka pemikiran ini merupakan konsekuensi dari korporasi sebagai subjek hukum, yaitu dalam hal korporasi melanggar atau tidak memenuhi kewajiban tertentu yang disyaratkan oleh undang-undang, maka subjek hukum buatan tersebut harus bertanggung jawab secara pidana.

Hal yang penting dari teori ini adalah subjek hukum harus bertanggung jawab terhadap akibat yang timbul, tanpa harus dibuktikan adanya kesalahan atau kelalaiannya. Hal ini juga diperjelas dalam definisi perbandingan untuk seseorang yang melakukan perbuatan yang merugikan, di mana dikatakan bahwa: "When a person is automatically considered responsible, without proof of negligence, for damages due to items which are universally known to be highly dangerous, like owning poisonous animals or explosives."

Pelanggaran kewajiban atau kondisi tertentu oleh korporasi ini dikenal dengan istilah strict liability offences. Contoh dari rumusan undang-undang yang menetapkan sebagai suatu delik bagi korporasi adalah dalam hal: (a) korporasi yang menjalankan usahanya tanpa izin; (b) korporasi pemegang izin yang melanggar syarat-syarat (kondisi/ situasi) yang ditentukan dalam izin itu; (c) korporasi yang mengoperasikan kendaraan yang tidak diasuransikan di jalan umum. ${ }^{17}$

\section{Vicarious Liability}

Berdasarkan teori ini, maka secara umum dapat dikatakan bahwa atasan harus bertanggung jawab atas apa yang dilakukan oleh bawahannya. Sebagaimana didefinisikan bahwa prinsip hukum vicarious liability adalah seseorang bertanggung jawab untuk perbuatan yang dilakukan oleh orang lain, ketika keduanya termasuk dalam suatu bentuk kegiatan gabungan atau kegiatan bersama. Doktrin tersebut secara tradisional merupakan konsepsi

Ibid. 36.

16 Barda Nawawi Arief, Kapita Selekta Hukum Pidana (PT. Citra Aditya Bakti 2010) 237-238.

17 Ibid. 
yang muncul dari sistem hukum common law, yang disebut sebagai respondeat superior, yaitu tanggung jawab sekunder yang muncul dari doctrine of agency, di mana atasan bertanggung jawab atas perbuatan yang dilakukan oleh bawahannya.

Di antara para ahli yang mengkaji teori ini, dengan bertolak dari hubungan pekerjaan dalam kaitannya dengan vicarious liability, Peter Gillies membuat beberapa pemikiran sebagai berikut. Pertama, suatu perusahaan (seperti halnya dengan manusia sebagai pelaku/ pengusaha) dapat bertanggung jawab secara mengganti untuk perbuatan yang dilakukan oleh karyawan/agennya. Pertanggungjawaban demikian hanya timbul untuk delik yang mampu dilakukan secara vicarious. Kedua, dalam hubungannya dengan employment principle, delik-delik ini sebagian besar atau seluruhnya merupakan summary offences yang berkaitan dengan peraturan perdagangan. Ketiga, kedudukan majikan atau agen dalam ruang lingkup pekerjaannya, tidaklah relevan menurut doktrin ini. Tidaklah penting bahwa majikan, baik sebagai korporasi maupun secara alami tidak telah mengarahkan atau memberi petunjuk/perintah pada karyawan untuk melakukan pelanggaran terhadap hukum pidana. (Bahkan, dalam beberapa kasus, vicarious liability dikenakan terhadap majikan walaupun karyawan melakukan perbuatan bertentangan dengan instruksi, berdasarkan alasan bahwa perbuatan karyawan dipandang sebagai telah melakukan perbuatan itu dalam ruang lingkup pekerjaannya). Oleh karena itu, apabila perusahaan terlibat, pertanggungjawaban muncul sekalipun perbuatan itu dilakukan tanpa menunjuk pada orang senior di dalam perusahaan. Perlu dikemukakan bahwa doktrin ini dapat berlaku dengan didasarkan pada prinsip pendelegasian wewenang atau the delegation principle. Jadi, niat jahat atau mens rea atau $a$ guilty mind dari karyawan dapat dihubungkan ke atasan apabila ada pendelegasian kewenangan dan kewajiban yang relevan menurut undang-undang. ${ }^{18}$

\section{Identification}

Pertanggungjawaban pidana langsung atau direct liability (yang juga berarti nonvicarious), menyatakan bahwa para pegawai senior korporasi, atau orang-orang yang mendapat delegasi wewenang dari mereka, dipandang dengan tujuan tertentu dan dengan cara yang khusus, sebagai korporasi itu sendiri, dengan akibat bahwa perbuatan dan sikap batin mereka dipandang secara langsung menyebabkan perbuatan-perbuatan tersebut, atau merupakan sikap batin dari korporasi. Ruang lingkup tindak pidana yang mungkin dilakukan oleh korporasi sesuai dengan prinsip ini lebih luas, dibanding dengan apabila didasarkan pada doktrin vicarious. 
Teori tersebut menyatakan bahwa perbuatan atau kesalahan pejabat senior (senior officer) diidentifikasi sebagai perbuatan atau kesalahan korporasi. Konsepsi ini disebut juga doktrin alter ego atau teori organ. ${ }^{19}$ Dalam pandangan Barda Nawawi Arief, pengertian pejabat senior korporasi dapat bermacammacam. Meskipun pada umumnya, pejabat senior adalah orang yang mengendalikan perusahaan, baik sendiri maupun bersama-sama, yang biasa disebut para direktur dan manajer. Hal tersebut tergambar dalam pendapat para pakar maupun praktisi hukum berikut ini:

a. Didefinisikan dalam arti sempit di Inggris yaitu hanya perbuatan pejabat senior (otak korporasi) yang dapat dipertanggungjawabkan kepada korporasi. Sementara di Amerika Serikat, teori ini diartikan lebih luas yaitu tidak hanya pejabat senior/direktur, tetapi juga agen di bawahnya.

b. Hakim Reid dalam perkara Tesco Supermarkets Ltd. (1972): (a) untuk tujuan hukum, para pejabat senior biasanya terdiri dari dewan direktur, direktur pelaksana dan pejabatpejabat tinggi lainnya yang melaksanakan fungsi manajemen dan berbicara serta berbuat untuk perusahaan; (b) konsep pejabat senior tidak mencakup "semua pegawai perusahaan yang bekerja atau melaksanakan petunjuk pejabat tinggi perusahaan. c. Lord Morris: Pejabat senior adalah orang yang tanggung jawabnya mewakili/melambangkan pelaksana dari the directing mind and will of the company.

d. Viscount Dilhorne: Pejabat senior adalah seseorang yang dalam kenyataannya mengendalikan jalannya perusahaan (atau ia merupakan bagian dari para pengendali) dan ia tidak bertanggung jawab pada orang lain dalam perusahaan itu.

e. Lord Diplock: Mereka-mereka yang berdasarkan memorandum dan ketentuan yayasan atau hasil keputusan para direktur atau putusan rapat umum perusahaan, telah dipercaya melaksanakan kekuasaan perusahaan.

f. House of Lord: Manajer dari salah satu toko/supermarket berantai tidak dipandang sebagai pejabat senior. ia tidak berfungsi sebagai "the directing mind and will of the company." Ia merupakan salah seorang yang diarahkan. Ia merupakan salah seorang yang dipekerjakan, tetapi ia bukan utusan/delegasi perusahaan yang diserahi tanggung jawab.

g. Hakim Bowen C.A. dan Franki (dalam perkara Universal Telecasters, 1977, di Australia): Manajer penjualan (the sales manager) dari perusahaan yang mengoperasikan stasiun televisi, bukanlah senior officer. 
h. Hakim Nimmo (hakim ketiga dalam perkara Universal Telecasters): (a) Manajer penjualan dapat diidentifikasikan sebagai perusahaan, yaitu sebagai senior officer; (b) Walaupun orang itu (manajer penjualan) tidak memiliki kekuasaan manajemen yang umum, tetapi ia mempunyai kebijaksanaan manajerial (managerial discretion) yang relevan dengan bidang operasi perusahaan yang menyebabkan timbulnya delik. Dengan kata lain, dalam pandangannya, pejabat perusahaan dapat menjadi senior officer dalam bidang yang relevan, walaupun tidak untuk semua tujuan.

i. Supreme Court Queensland: Manajer perusahaan penjual motor (motor dealer) dapat dipandang sebagai senior officer, dapat juga sebagai the sales manager yang kepadanya manajer mendelegasikan pengendalian bisnis selama manajer absen.

j. Supreme Court Australia Selatan (merefleksikan pandangan Nimmo di atas): Dalam delik lalu lintas, manajer operasi dan juga manajer yang bertanggung jawab pada pengawasan kendaraan dan sopir dapat dipandang sebagai senior officer. ${ }^{20}$

\section{Ragam Kejahatan Korporasi Pemegang Saham dan Direksi}

Kejahatan korporasi terdiri dari: conflict of interest, pembukuan ganda, kejahatan teknologi, korupsi dan pencurian aset. Pertama, konflik kepentingan (conflict of interest) dimulai dengan penunjukkan pejabat eksekutif dari internal family atau keluarga. Entah itu dari ayah, ibu, mertua, besan, anak, menantu, cucu, cucu menantu, keponakan dan hubungan keluarga lainnya seperti ipar, sepupu dan lainlain. Penunjukan pejabat eksekutif biasanya untuk mengamankan visi, misi dan rencana tersembunyi (hidden plan) dari pendiri perusahaan. Outsider directors bisa ditunjuk bila sudah teruji kesetiaan dan kepatuhan terhadap pendiri. Hal ini banyak terjadi di bankbank sehingga banyak bank-bank yang bangkrut saat menghadapi krisis karena semua diatur sedemikian rupa sehingga pengawas yaitu Bank Indonesia tidak bisa mendeteksi secepat mungkin.

Saat terjadi krisis 1998, banyak perusahaan perbankan yang bobrok karena kejahatan konflik kepentingan sehingga kredit yang seharusnya disalurkan ke masyarakat, disalurkan di grup sendiri. Cara-cara ini sekarang sudah mulai berkurang karena peraturan Bank Indonesia yang ketat sehingga tidak dimungkinkannya dilakukan lagi di mana Bank Indonesia melarang presiden direktur berasal dari keluarga, harus benar-benar independen. Jumlah komisaris dan direksi yang ada hubungan terkait harus minoritas bukan mayoritas. Tapi untuk perusahaan-perusahaan terbuka masih terlihat conflict of interest ini, belum ada larangan tegas seperti di dunia perbankan. 
Kita bisa lihat ada perusahaan televisi yang direksi dan komisarisnya masih dikuasai oleh hubungan keluarga sehingga outsider directors hanya sebatas nama saja untuk kekuasaan dan wewenangnya. Pengambilan keputusan semua kegiatan masih tetap pemegang saham sehingga apa yang diinginkan pemegang saham maka pemegang saham itu saja yang mengambil keputusan. Dalam hal ini Bapepam seharusnya dapat melakukan perubahan peraturan seperti yang dilakukan oleh Bank Indonesia sehingga keinginan pemegang saham yang berusaha melakukan kejahatan perusahaan dapat dicegah melalui peraturan-peraturan yang ketat.

Banyak juga terjadi permainan harga saham yang dilakukan oleh pemegang saham seolah-olah banyak investor yang beli sehingga harga saham bergolak naik, padahal saham tersebut dibeli oleh groupnya sendiri dengan nama outsider directors atau karyawan karena wewenang pemegang saham masih tak terbatas. Saat harga naik lalu saham tersebut dijual semua sehingga harga turun dan para investor eksternal akan mengalami kerugian besar padahal kegiatan perusahaan tidak ada perubahan (statis). OJK mengatur perusahaan-perusahaan yang ditengarai melakukan kejahatan korporasi dengan mengaudit pembayaran pajaknya dan dicek secara akurat transaksi-transaksi fiktifnya.

Kedua, pembukuan ganda. Pembukuan ganda banyak dilakukan oleh family ownership. Tujuannya adalah memperkecil pembayaran pajak.
Sekarang lebih canggih lagi yaitu dengan mendirikan yayasan sehingga aliran dana ke yayasan perlu diteliti secara cermat. Karena bila sudah menggunakan yayasan, kontrol masyarakat sudah putus karena masyarakat berpikir bahwa yayasan menyumbangkan dananya untuk membantu kegiatan sosial seperti beasiswa, penanganan banjir, kebakaran, khitanan massal, pengobatan massal dan sebagainya. Padahal semua itu adalah kegiatan kejahatan yang disembunyikan oleh pemegang saham dengan mengelabuhi seolah-olah sebagai kegiatan corporate social responsibility.

Kalau mau terbuka secara benar semua itu tindakan kejahatan yang dilakukan oleh pemegang saham untuk mengambil deviden dengan membayar pajak sekecil-kecilnya dan juga yayasan dijadikan sebagai sarana untuk kegiatan pencucian uang sehingga terhindar dari pengawasan masyarakat dan pajak. Bila petugas pajak datang biasanya pembukuan yang palsu yang ditunjukkan, tapi kalau untuk menilai prestasi outside directors maka yang asli yang digunakan.

Memang hal ini sulit untuk membuktikannya karena semua dokumen penting sebagai alat bukti disimpan oleh pemegang saham dan orang-orang yang dipercaya oleh pemegang saham untuk mengamankan. Ini adalah pekerjaan rumah buat petugas pajak untuk mengecek kejahatan perusahaan melalui pembukuan ganda, Seandainya ditemukan oleh petugas pajak maka 
jalan damai akan ditempuh oleh pemegang saham dengan memberikan gratifikasi atau suap kepada petugas pajak yang imannya sangat rendah sehingga mudah tergiur dengan pemberian uang suap tersebut.

Kita bisa lihat pembelian pulsa atau transaksi lainnya melalui mesin ATM seharusnya dikenakan PPN tapi kenyataannya semua bisa di negosiasi antara perusahaan dan petugas pajak. Hal ini juga bisa menjadi pekerjaan rumah buat Badan Pemeriksa Keuangan untuk mengaudit kembali kejujuran dari institusi perpajakan apakah mereka sudah melakukan audit secara benar atau tidak.

Ketiga, kejahatan teknologi. Kejahatan teknologi ini memang harus diperiksa oleh petugas yang benar-benar mengerti tentang information techonology (IT). Petugas yang kemampuannya mengaudit secara manual maka tidak akan menemukan kejahatan melalui teknologi ini. Biasanya institusi audit terkait akan membentuk audit keuangan, audit perusahaan, audit manajemen dan audit IT. Pembukuan ganda bisa dilakukan juga dengan IT sehingga program dibuat ganda untuk yang resmi ke pajak dan yang tidak resmi ke laporan direksi ke pemegang saham.

Beberapa negara sudah melakukan antisipasi dengan cara mendidik petugas pajak untuk mengerti tentang akuntansi dan IT lalu ditugaskan untuk melamar sebagai karyawan perusahaanperusahaan besar. Setelah mereka diterima sebagai karyawan maka mereka mendapat dua status yaitu sebagai karyawan pajak dan sebagai karyawan perusahaan besar. Setelah beberapa tahun tidak dicurigai maka petugas bisa mengcopy semua kegiatan perusahaan, atas dasar informasi karyawan tersebut maka dapat tertangkap tangan karena memiliki bukti dan akses langsung. Di Indonesia sepertinya juga sudah dilakukan untuk menekan perusahaanperusahaan keluarga yang senang melakukan kejahatan perusahaan melalui kejahatan teknologi.

Keempat, korupsi. Kejahatan korupsi ini sangat kompleks sekali dilakukan oleh perusahaan yaitu melalui pendirian anak perusahaan di luar negeri untuk menghindari pajak dan melakukan transaksi fiktif. Misalkan ada penjualan asset yang nilai jualnya berlipat-lipat ganda dibanding nilai buku. Atas selisih tersebut perusahaan seharusnya membayar pajak penghasilan atas selisih nilai jual dan nilai beli.

Untuk menghindari pajak, perusahaan dapat melakukan penandatanganan jual beli ke luar negeri sehingga sesuai peraturan negara tersebut maka pajak yang dibayarkan menjadi lebih kecil. Perusahaan dapat juga melakukan transaksi dengan keuntungan yang besar maka untuk bisa memperkecil pembayaran pajak seolah-olah ada transaksi ekspor impor dimana perusahaan menyetor sejumlah uang ke rekening perusahaan cabang diluar negeri lalu perusahaan diluar negeri mengirim dokumen seolah-olah ada transaksi ekspor impor. Dengan demikian perusahaan akan mencatat 
sebagai impor barang sehingga tidak ada pembayaran pajak. Jadi strategi pembukaan cabang di luar negeri adalah untuk mengelabuhi pembayaran pajak di dalam negeri karena ada loop hole peraturan di luar negeri. Di perbankan juga sama dengan pendirian cabang bank di Cayman Island, Nassau, Solomon Island. Semua itu adalah korupsi yang dilakukan oleh perusahaan karena ada loop hole yang secara hukum terlindungi. Banyak sekali wealth management atau private banking menampung nasabah-nasabah yang berniat melakukan money laundering sekaligus menghindari pembayaran pajak penghasilan atas bunga deposito.

Hal ini adalah pekerjaan rumah dari Bank Indonesia yang dapat bekerja sama dengan Direktorat Jenderal Pajak untuk menangkap perusahaanperusahaan atau bank-bank yang berusaha menghindari pajak. Kejahatan korupsi ini banyak sekali dilakukan dengan banyak pula modus operandinya. Seperti di Nassau, ada bank-bank swasta di Indonesia yang memiliki cabang di nassau pada kenyataannya tidak ada plang namanya di Nassau, di sana banyak sekali namanama bank tapi yang bertransaksi tidak banyak mungkin banyak dilakukan dinegara-negara asal yang berupa transaksi fiktif atau akal-akalan saja.

Pemerintah dapat melakukan cross check dan audit langsung bank-bank yang melakukan korupsi atau melindungi perbuatan pencucian uang ini. Korupsi lain adalah pembayaran pajak atas pelayanan sebesar $10 \%$ yang dikenakan pada konsumen. Pada kenyataannya perusahaan-perusahaan tersebut tidak membayar seperti yang dibebankan kepada semua konsumen. Lihat saja restauran-restauran pasti mengenakan $10 \%$ pajak pada pembeli tapi tidak disetorkan ke pajak, hal ini juga merupakan korupsi yang harus diberantas sehingga APBN dapat meningkat.

Korupsi lainnya yaitu pendirian anak cabang oleh ATPM-ATPM hal ini dilakukan agar bisa menunda pembayaran PPN maupun PPn BM selalu beberapa hari atau beberapa bulan sehingga uang dapat diputarkan terlebih dahulu untuk mencari keuntungan. Kejahatan perusahaan juga banyak dilakukan di perusahaan televisi dengan menukarkan sejumlah biaya iklan dengan biaya lainnya dengan kontrak. Secara hukum benar tapi pada kenyataannya adalah gratifikasi atau korupsi yang diputar-putar sehingga seolah-olah tidak terjadi korupsi atau tindak kejahatan.

Kelima adalah pencurian aset. Pencurian aset ini banyak dilakukan oleh perusahaan keluarga dengan cara semua keperluan komisaris dan direksi dari perusahaan keluarga atas nama keluarga atau pribadi kemudian saat masa pembukuan sudah habis maka di write off dan uang tidak masuk ke perusahaan tapi masuk ke kantong pribadi keluarga (pemegang saham). Hal ini bisa dalam pembelian mobil, rumah atau aset lainnya. Pencurian aset juga dilakukan oleh perusahaan keluarga dengan membebankan semua biaya rumah tangga keluarga ke perusahaan baik dalam bentuk biaya pesta, biaya 
keluar negeri, biaya hidup sehari-hari dan biaya kebutuhan rumah tangga semua masuk ke biaya perusahaan. Dengan demikian gaji mereka utuh karena pengeluaran biaya dibebankan ke perusahaan. Memang ini biaya kecil dibandingkan biaya lainnya, tapi bisa dimasukkan dalam kategori pencurian asset perusahaan oleh keluarga agar pajak perusahaan menjadi lebih kecil.

\section{Pertanggungjawaban Pidana Pemegang Saham dan Direksi}

Dalam korporasi, direksi dan komisaris sebagai salah satu organ vitalnya merupakan pemegang amanah (fiduciary) yang harus berperilaku sebagaimana layaknya pemegang kepercayaan. Di sini komisaris dan direktur memiliki posisi fiducia dalam pengurusan perusahaan dan mekanisme hubungannya harus secara fair. Menurut pengalaman tradisi common law hubungan itu dapat didasarkan pada teori fiduciary duty. Hubungan fiduciary tersebut didasarkan atas kepercayaan dan kerahasiaan (trust and confidence) yang dalam peran ini meliputi, ketelitian (scrupulous), itikad baik (good faith) dan keterusterangan (candor). ${ }^{21}$ Dalam memahami hubungan atas dasar kepercayaan (fiduciary relationship), tradisi common law mengakui bahwa orang yang memegang kepercayaan secara alamiah memiliki potensi untuk menyalahgunakan wewenangnya. Oleh sebab itu hubungan pemegang kepercayaan tersebut harus didasarkan pada standar yang tinggi. ${ }^{22}$

Negara-negara common law seperti Amerika Serikat telah mempunyai standar yang jelas untuk menentukan apakah seorang direktur dapat dimintai pertanggungjawabannya atas tindakan yang diambilnya, yaitu didasarkan pada standar duty of loyality dan duty of care. Kewajiban utama direktur ditujukan kepada perusahaan secara keseluruhan, bukan kepada pemegang saham baik secara individu maupun kelompok, ${ }^{23}$ sesuai dengan posisi seorang direktur sebagai sebuah trustee dalam perusahaan. Posisi ini mengharuskan seorang direktur untuk tidak bertindak ceroboh dalam melakukan tugasnya (duty of care). ${ }^{24}$ Selain itu dalam melakukan tugasnya tersebut seorang direktur tidak boleh mengambil keuntungan untuk dirinya sendiri atas perusahaan of loyality). ${ }^{25}$ Pelanggaran terhadap kedua

21 Teori fiduciary duty adalah suatu kewajiban yang ditetapkan undang-undang bagi seseorang yang memanfaatkan seseorang lain, dimana kepentingan pribadi seseorang yang diurus oleh pribadi lainnya, yang sifatnya hanya hubungan atasan-bawahan sesaat. Orang yang mempunyai kewajiban ini harus melaksanakannya berdasarkan suatu standar dari kewajiban (standard of duty) yang paling tinggi sesuai dengan yang dinyatakan oleh hukum. Sedangkan fiduciary ini adalah seseorang yang memegang peran sebagai suatu wakil (trustee) atau suatu peran yang disamakan dengan sesuatu yang berperan sebagai wakil, dalam hal ini peran tersebut didasarkan kepercayaan dan kerahasiaan (trust and confidence) yang dalam peran ini meliputi, ketelitian (scrupulous), itikad baik (good faith) dan keterusterangan (candor). Fiduciary ini termasuk hubungan seperti, pengurus atau pengelola, pengawas, wakil atau wali, dan pelindung (guardian). Termasuk juga di dalamnya seorang lawyer yang mempunyai hubungan fiduciary dengan client-nya. Bryan A. Garner ed., Op.Cit. 625.

22 Charity Scott, 'Caveat Vendor: Broker-Dealer Liability Under the Securities Exchange Act' (1989) 9 Securities Regulation Law Journal 274, 291. 
prinsip tersebut dalam hubungannya dengan fiduciary duty dapat menyebabkan direktur untuk dimintai pertanggungjawaban hukum secara pribadi terhadap perbuatan yang dilakukannya, baik kepada para pemegang saham maupun kepada pihak lainnya. ${ }^{26}$

Doktrin atau prinsip fiduciary duty ini dapat dijumpai dalam UndangUndang Nomor 40 Tahun 2007 tentang Perseroan Terbatas (UU PT). Menurut Pasal 179 ayat (1) UU PT pengurusan PT dipercayakan kepada direksi. Lebih jelasnya Pasal 82 UUPT menyatakan bahwa direksi bertanggung jawab penuh atas pengurusan perseroan untuk kepentingan dan tujuan perseroan serta mewakili perseroan baik di dalam maupun di luar pengadilan. Sedangkan Pasal 85 UUPT menetapkan bahwa setiap anggota direksi wajib dengan itikad baik dan penuh tanggung jawab menjalankan tugas untuk kepentingan dan usaha perseroan. Pelanggaran ketentuan ini dapat menyebabkan direksi bertanggung jawab penuh secara pribadi apabila yang bersangkutan bersalah atau lalai menjalankan tugasnya tersebut.

Terkait dengan posisi direktur, sangat penting untuk mengontrol perilaku dari para direktur yang mempunyai posisi dan kekuasaan besar dalam mengelola perusahaan, termasuk menentukan standar perilaku (standart of conduct) untuk melindungi pihakpihak yang akan dirugikan apabila seorang direktur berperilaku tidak sesuai dengan kewenangannya atau berperilaku tidak jujur. ${ }^{27}$ Untuk membebankan pertanggungjawaban terhadap direktur atau pengurus korporasi, maka harus dibuktikan adanya pelanggaran terhadap kewajiban yang dimilikinya. Pengurus korporasi dalam hal ini harus dapat dibuktikan telah melanggar good faith yang dipercayakan padanya dalam menjalan korporasi atau perusahaan, sebagaimana diatur dalam prinsip fiduciary duty.

Jika dihubungkan dengan identification theory dalam wacana common law sebagaimana telah diuraikan di atas, kesalahan yang dilakukan oleh anggota direksi atau pejabat korporasi lainnya atau bahkan pemegang saham (pemilik) hanya dapat dibebankan pada korporasi jika memenuhi syarat: (1) tindakan yang dilakukan oleh mereka berada dalam batas kepemilikan, atau tugas, atau instruksi yang diberikan pada mereka; (2) bukan merupakan penipuan yang dilakukan terhadap perusahaan; (3) dimaksudkan untuk menghasilkan atau mendatangkan keuntungan bagi korporasi. Dengan kata lain, jika salah

23 Janet Dine, Company Law (Sweet \& Maxwell 2001) 217.

24 Denis Keenan dan Josephine Biscare, Smith \& Keenan's Company Law For Students (Financial Times-Pitman Publishing 1996) 317.

25 Joel Seligman, Corporations: Cases and Materials (Little Brown and Company 1995).

26 Philip Lipton dan Abraham Herzberg, Understanding Company Law (The Law Book Co. 1992) 342.

27 Janet Dine, Op.Cit. 179. 
satu syarat ini tidak dipenuhi, maka kesalahan tersebut tidak dapat dipikul oleh korporasi, namun harus dipikul secara pribadi oleh organ korporasi yang melakukan tindakan tersebut.

Berkaitan dengan anggota direksi atau pejabat korporasi yang mengambil tindakan untuk kepentingan dan keuntungan bagi korporasi, terdapat doktrin dalam hukum korporasi yang melindungi para direktur yang beritikad baik yang dikenal dengan sebutan business judgment rule. Penerapan teori ini mempunyai misi utama untuk mencapai keadilan, khususnya bagi direktur perseroan terbatas dalam melakukan suatu keputusan bisnis. ${ }^{28}$

Salah satu tolak ukur untuk memutuskan apakah suatu kerugian tidak disebabkan oleh keputusan bisnis (business judgment) yang tidak tepat sehingga dapat menghindar dari pelanggaran prinsip duty of care adalah: Pertama, memiliki informasi tentang masalah yang akan diputuskan dan percaya bahwa informasi tersebut benar. Kedua, tidak memiliki kepentingan dengan keputusan dan memutuskan dengan itikad baik. Ketiga, memiliki dasar rasional untuk mempercayai bahwa keputusan yang diambil adalah yang terbaik bagi perusahaan. ${ }^{29}$
Apabila terbukti bahwa tindakan atau keputusan direktur untuk memberlakukan kebijakan korporasi didasarkan atas business judgmentyang tepat, maka jika ternyata tindakan tersebut menimbulkan kerugian yang melahirkan pertanggungjawaban pidana, hal itu tidak dapat dibebankan pada pribadi pengurus (direksi atau pejabat korporasi lainnya), tetapi dibebankan pada korporasi. Pertanggungjawaban oleh pengurus hanya dimungkinkan apabila terbukti terjadi pelanggaran duty of care dan duty of loyalty.

\section{PENUTUP}

Pemberantasan kejahatan korporasi dapat menurunkan tingkat korupsi sehingga pemerintahan yang bersih dan berwibawa akan terwujud. Tapi bila dalam hal yang kecil saja tidak diatasi maka kejahatan-kejahatan lainnya akan semakin merajalela. Hal ini belum termasuk kejahatan perusahaan yang dilakukan dengan melakukan suap, pemberian gratifikasi baik secara tunai maupun non tunai seperti membiayai perjalanan keluar negeri untuk pejabat dan keluarganya termasuk biaya oleholehnya dan semua akan dibebankan ke perusahaan.

28 Teori business judgment rule mengalami perkembangan sebagai yurisprudensi dalam prinsip common law di Amerika Serikat yang dimulai dengan putusan Lousianna Supreme Court, dalam kasus Percy v. Millaudon pada tahun 1829. Lihat Dennis J. Block, Nancy R. Barton dan Stephen A. Radin, The Business judgment Rule Fiduciary Duties of Corporate Directors (Prentice Hall 1990) 4.

29 Detlev F. Vagts, Basic Corporation Law: Materials-Cases-Text (The Foundation Press Inc. 1989) 212. Lihat juga Robert Charles Clark, Corporate Law (Little, Brown and Co. 1986) 123 yang menyatakan bahwa business judgement rule adalah " a presumption that in making a business decision, the director of corporation acted on an informed basis in good faith and in the the honest belief that the action was taken in the best interest of the company" 
Pertimbangan dampak yang dapat ditimbulkan oleh kejahatan korporasi baik bagi masyarakat, perekonomian, pemerintahan dan aspek-aspek lainnya yang berbahaya, bahkan lebih serius dibandingkan dengan dampak yang ditimbulkan oleh bentuk-bentuk kejahatan yang konvensional, membutuhkan konsistensi dan landasan yang solid dalam hukum untuk dapat membebankan pertanggungjawaban pidana kepada korporasi baik pemegang saham maupun direksi. Dalam berbagai kasus terdapat pengaturan menyangkut pertanggungjawaban ini. Selain itu, diperlukan perhatian studi yang lebih mendalam, baik di kalangan akademisi, profesional maupun aparat penegak hukum, guna membangun suatu kerangka teoretis bagi pertanggungjawaban pidana korporasi. Hal ini hendaknya diimbangi pula dengan upaya peningkatan kualitas dan kemampuan para penegak hukum yang akan menerapkannya.

\section{DAFTAR BACAAN}

\section{Buku}

Arief, Barda Nawawi, Kapita Selekta Hukum Pidana (PT. Citra Aditya Bakti 2010).

Block, Dennis J., Nancy R. Barton dan Stephen A. Radin, The Business judgment Rule Fiduciary Duties of Corporate Directors (Prentice Hall 1990).
Box, Steven, Power, Crime and Mystification (Tavistock Publication 1983).

Clark, Robert Charles, Corporate Law (Little, Brown and Co. 1986).

Dine, Janet, Company Law (Sweet \& Maxwell 2001).

Dirdjosisworo, Soedjono, Kejahatan Bisnis - Orientasi dan Konsepsi (Mandar Maju 1994).

Garner, Bryan A., ed., Black's Law Dictionary (West Publishing Co. 2003).

Gillies, Peter, Criminal Law (The Law Book Co. 1990).

Gross, Hyman, A Theory of Criminal Justice (Oxford University Press 1979).

Keenan, Denis, dan Josephine Biscare, Smith \& Keenan's Company Law For Students (Financial Times-Pitman Publishing 1996).

Lipton, Philip, dan Abraham Herzberg, Understanding Company Law (The Law Book Co. 1992).

Muladi dan Barda Nawawi Arief, Teoriteori dan Kebijakan Pidana (Alumni, 1998).

Seligman, Joel, Corporations: Cases and Materials (Little Brown and Co. 1995).

Singgih, Kejahatan Korporasi yang Mengerikan (Pusat Studi Hukum Bisnis Fakultas Hukum Universitas Pelita Harapan 2005). 
Susanto, I.S., Kejahatan Korporasi,

(Badan Penerbit Universitas

Diponegoro 1995).

Vagts, Detlev F., Basic Corporation Law:

Materials-Cases-Text

(The

Foundation Press Inc. 1989).

\section{Jurnal dan Artikel}

Purba, Erwin, 'Menghukum Korporasi:

Mengurangi Kerugian Negara'

Majalah Forum Keadilan (2013) Mei.

Scott, Charity, 'Caveat Vendor: BrokerDealer Liability Under the Securities Exchange Act' (1989) 9 Securities Regulation Law Journal 274.

\section{Internet}

Rusmana, 'Pertanggungjawaban Korporasi dalam Tindak Pidana Perikanan' <http:// www.solusihukum.com/artikel/ artikel45.php> diakses 3 Februari 2014. 